\title{
THE EFFECT OF WATER RENEWAL ON GROWTH OF Clarias gariepinus FINGERLINGS
}

\author{
Victor Tosin Okomoda*, Lateef Oloyede Tiamiyu, Matins Iortim \\ Department of Fisheries and Aquaculture, University of Agriculture, Makurdi, Nigeria \\ *Corresponding author, Email: okomodavictor@yahoo.com
}

\section{ARTICLE INFO}

Received: 7 December 2015

Received in revised form: 22 February 2016

Accepted: 8 March 2016

Available online: 8 March 2016

\begin{abstract}
The aim of this study was to determine the effect of different water change frequency on the growth of African catfish Clarias gariepinus. Fingerlings with initial mean weights of $7.02 \pm 0.05 \mathrm{~g}$ were stocked (50 fish each) in fifteen concrete tanks $(2 \times 2 \times 2 \mathrm{~m})$ and were conditioned under five different treatments of water renewal, namely: TRT1 (no water change), TRT2 (water renewed daily), TRT3 (water renewed after four days), TRT4 (water renewed after eight days) and TRT5 (water renewed after fourteen days). After 56 days of feeding, results revealed best growth performance of fingerlings in tanks with water renewal frequency of TRT3 and TRT4. Similarly, survival was higher in these frequencies compared to the others; the control treatment, however, had the least performance for all parameters measured. It is therefore recommended that water renewal should be done once between four and eight days to enhance growth of African catfish fingerlings reared in a static system.
\end{abstract}

Okomoda, V. T., Tiamiyu, L. O., Iortim, M. (2016): The effect of water renewal on growth of Clarias gariepinus fingerlings. Journal of Fisheries, 74, 25-29. DOI: 10.1515/cjf-2016-0005

\section{INTRODUCTION}

Aquaculture continues to grow more rapidly than all other animal food-producing sectors in the world (FAO, 2006). Unlike terrestrial farming, where the bulk of the production is based on a limited number of species, aquaculture produces more than 220 species (FAO, 2012). Fish farming is particularly an important aspect of aquaculture as it provides about $40 \%$ of the dietary intake of animal protein and constitutes a third of the world's supply of fish products; it is lower in total fat and calories than meat or poultry, hence a healthy protein choice (Gramma et al., 2011). Fish culture is considered one of the promising resources of animal proteins for the future (Neuman, 2004). Fish perform all its bodily functions in water, hence understanding the physical and chemical qualities of water is critical to successful aquaculture. According to Ajana et al. (2006), water determines the success or failure of an aquaculture operation to a greater extent. In heavily stocked and artificially fed fish ponds, many problems associated with water quality such as organic pollution, deficiency of oxygen, increased level of free carbon dioxide and increase in ammonia-nitrogen ratio are frequently occurring (Basu, 2011). Failure to maintain an adequate water quality regime in ponds may cause parasitic infection or other diseases and conditions which are very detrimental to the fish (Collins, 1994).

Natural self-cleaning mechanism of the water bodies helps keep water quality at desired level for better performance of fish, however, under culture, effort has to be made continually by maintaining adequate water quality for better growth performance of the fish. Aeration is one method commonly used to improve dissolved oxygen (Agarwal, 1999). Boyd (1990) also reported that aeration system is one of the best methods to oxidize ammonia to nitrate or to 
adjust $\mathrm{pH}$ and to volatilize the ammonia, however, aeration does not solve other water quality problems (e.g. TDS, turbidity, conductivity, etc.). Technological advancement in fish culture has seen the development of advanced system which helps maintain desirable water quality in ponds; this includes but is not limited to race way system, flow through system, re-circulatory aquaculture system (RAS), bio flux system, etc. The applicability of this system, however, is constrained by size, price, availability of electricity, water supply as well as technological knowledge of its operation, hence many still use the conventional static system for commercial fish production and fisheries research which involves timed water renewal procedure to maintain water quality. Olivier et al. (2006) reported responses of fish farmers to water renewal of small, medium and large ponds in Thai Binh Province, Northern Vietnam; they gathered that larger percentages of fish farmers renew water weekly (56-79\%), while others rarely renew water in ponds (14$22 \%)$. Structured questionnaires administered before this study were designed, however, revealed an even spread of response with no particular preference on frequency of water renewal in ponds. To date, there is no known standard for the frequency of water change in static systems and the subject matter has been poorly studied; previous research had focused on the effect of isolated water quality parameters (Oxygen, $\mathrm{pH}, \mathrm{CO}_{2}$, etc.) on the growth performance of fish (Buentello et al., 2000; Boyd, 2001). The lack of information about the effect of constant water renewal on fish growth inspired the design of this research; hence, the study was conducted using a highly hardy fish (Clarias gariepinus) native to Africa and widely cultured in the world to investigate the subject matter.

\section{MATERIALS AND METHODS}

The study was conducted at the Fish Hatchery Unit of the Department of Fisheries and Aquaculture, South core, University of Agriculture, Makurdi, Nigeria. One thousand fingerlings of Clarias gariepinus with average weight of 7.02 $\pm 0.05 \mathrm{~g}$ were obtained from the University research farm and acclimatised for two weeks. Out of these, fifty fingerlings of fish were stocked in triplicate batches of concrete pond measuring $2 \times 2 \times 2$ meters ( 750 total fingerling used) and fed Coppens $^{\circ}$ feed $(45 \%$ CP, $1.5 \%$ fiber, $8.2 \%$ moisture, $9.5 \%$ ash) for eight weeks.

The frequency of water renewal for this study was selected from the result of carefully structured questionnaires (Appendix 1) administered to members of the Fisheries Society of Nigeria. The following frequencies were selected: daily water change (TRT 2), every four days water change (TRT3), weekly water change (TRT4) and once every two weeks water change (TRT 4). Some respondents also indicated that they do not change water in static systems so we added this as control (TRT1).

Water quality parameters such as temperature, $\mathrm{pH}$, conductivity, total dissolved solids (TDS) and dissolved oxygen (DO) concentration were routinely monitored in the ponds using digital multi-parameter checker (HI 98126). After feeding the fish for eight weeks, growth performance and nutrient utilization were assessed using the relations below:

(a) Mean Initial Weight $\left(\right.$ MIW) $=\frac{\text { TotallnitialWeightofFingerlings }}{\text { TotalNumberofFingerlings }}$

(b) Mean Weight Gain (MWG) = Mean final weight - Mean initial weight

(c) Growth Rate $=\frac{\text { Meanfinalweight-MeanInitialWeight } X 100}{\text { DurationoftheExperiment }}$

(d) Specific Growth Rate (\%/day) $=\frac{\log _{e}\left(w t_{2}\right)-\log _{e}\left(w t_{1}\right)}{t_{2}-t_{1}}$

Where $\mathrm{Wt}_{1}=$ Initial weight gain

$$
\begin{aligned}
& \mathrm{Wt}_{2}=\text { Final weight gain } \\
& \mathrm{T}_{2}-\mathrm{T}_{1}=\text { Duration (in days) considered between } \mathrm{Wt}_{2} \\
& \text { and } \mathrm{Wt}_{1}
\end{aligned}
$$

(e) Feed conversion ratio $(F C R)=\frac{\text { dryfeedintake }}{\text { wetweightgain }}$

(f) Protein efficiency ratio $=\frac{\text { wetweightgain }}{\text { proteinfed }}$

Where Protein fed $=\frac{\% \text { proteinindiet } \times \text { totaldietconsumed }}{100}$

(g) \% survival rate $=\frac{\text { totalnumberoffish-mortality }}{\text { totalnumberoffish }} \times 100$

Statistics of different variables measured across the treatment were obtained using Minitab 14 Statistical Software for Windows (Minitab, Inc. 2004). Results were then subjected to analysis of variance and significant differences occurred; means were separated using Fisher's least significant difference test.

\section{RESULTS AND DISCUSSION}

This study clearly demonstrates that frequency of water renewal has significant effect on growth performance and nutrient utilization of African catfish fingerlings (Table 1).

Fish constantly disturbed by daily water change had lesser growth performance (MFW=17.9 g) compared to those raised in culture pond in which water was renewed every week (MFW=22.93 g) and ever four days (MFW=23.04 g). This is likely because of continuous interference with the dynamics of the pond system on a daily basis as a result of frequent disturbance of the water surface and possible frequent changes in water quality. The fish can be highly affected by an increase of stress (Tom, 1998; Moyle and Cech, 2000; Poon et al., 2002). In this study handling stress must have caused a poor performance of fish in ponds with water continually renewed. This also resulted in less feeding activity evident by large quantity of uneaten feed and high 
Table 1. Growth indices and food utilization parameters of Clarias gariepinus subjected to different frequency of water renewal

\begin{tabular}{lccccc}
\hline \hline Parameters & Trt 1 & Trt 2 & Trt 3 & Trt 4 & Trt 5 \\
\hline MIW (g) & $7.02 \pm 0.005$ & $7.01 \pm 0.00$ & $7.01 \pm 0.00$ & $7.02 \pm 0.005$ & $7.00 \pm 0.05$ \\
MFW (g) & $17.90 \pm 0.100^{\mathrm{c}}$ & $23.04 \pm 0.350^{\mathrm{a}}$ & $22.93 \pm 0.165^{\mathrm{a}}$ & $20.81 \pm 0.045^{\mathrm{b}}$ & $10.22 \pm 0.015^{\mathrm{d}}$ \\
MWG (g) & $10.89 \pm 0.095^{\mathrm{c}}$ & $16.03 \pm 0.350^{\mathrm{a}}$ & $15.92 \pm 0.165^{\mathrm{a}}$ & $13.80 \pm 0.050^{\mathrm{b}}$ & $3.80 \pm 0.010^{\mathrm{d}}$ \\
SGR (gday $)$ & $0.73 \pm 0.005^{\mathrm{c}}$ & $0.93 \pm 0.010^{\mathrm{a}}$ & $0.91 \pm 0.005^{\mathrm{a}}$ & $0.85 \pm 0.005^{\mathrm{b}}$ & $0.59 \pm 0.01^{\mathrm{d}}$ \\
FCR & $2.94 \pm 0.160^{\mathrm{b}}$ & $1.21 \pm 0.185^{\mathrm{d}}$ & $1.26 \pm 0.035^{\mathrm{d}}$ & $2.15 \pm 0.090^{\mathrm{c}}$ & $3.15 \pm 0.01^{\mathrm{a}}$ \\
PER & $0.19 \pm 0.001^{\mathrm{c}}$ & $0.29 \pm 0.006^{\mathrm{a}}$ & $0.28 \pm 0.003^{\mathrm{a}}$ & $0.25 \pm 0.001^{\mathrm{b}}$ & $0.16 \pm 0.001^{\mathrm{d}}$ \\
ANPU & $19.45 \pm 0.165^{\mathrm{c}}$ & $29.17 \pm 0.625^{\mathrm{a}}$ & $27.51 \pm 0.310^{\mathrm{a}}$ & $24.63 \pm 0.085^{\mathrm{b}}$ & $14.12 \pm 0.011^{\mathrm{d}}$ \\
\% SURVIVAL & $77.50 \pm 2.50^{\mathrm{a}}$ & $80.00 \pm 10.00^{\mathrm{a}}$ & $79.00 \pm 0.000^{\mathrm{a}}$ & $57.50 \pm 2.500^{\mathrm{b}}$ & $27.50 \pm 2.500^{\mathrm{c}}$ \\
\hline \hline
\end{tabular}

Means on the same row with different superscript differ significantly $(p<0.05)$; MIW= Mean initial weight, MFW= Mean final weight, MWG=Mean weight gain, $\mathrm{SGR}=$ Specific growth rate, $\mathrm{FCR}=$ Food conversion ratio, $\mathrm{PER}=$ Protein efficiency ratio, ANPU=Apparent net protein utilization

value of FCR recorded (2.94). Fish tend to spend more time looking for cover, increased swimming and concentration at the four edges of the tank was observed in these fishes, probably in an attempt to avoid been caught after a recent disturbance in the system. However, renewing water every week or every four days gave the fingerlings enough time to recover and resume active feeding, leading to better-feed conversion (1.26 and 1.21, respectively). Extending the time of water change to two weeks and beyond also negatively affected growth performance (MFW=20.81 g and $10.22 \mathrm{~g}$, respectively), basically due to water quality parameters of the system (Table 2) which deteriorated below recommended ranges. Boyd (2001) had reported that $\mathrm{pH}$ higher than 7 but lower than 9 is appropriate for fish culture. Adesulu (2001) also indicated that dissolved oxygen value below $4 \mathrm{mg} \mathrm{I}^{-1}$ begins to stress some tropical fishes, while $\mathrm{pH}$ at acidic level kills fishes due to corrosive effect.

He further opined that acidic water diminishes the appetites of fish and thus reduces their growth rate. This is in line with the observation of this study, as high percentages of uneaten feed were observed beyond weekly water renewal and in daily water renewal. Clarias gariepinus like any other catfish species require optimum levels of water quality parameters for survival, growth and reproduction (Egwui et al., 2014). Despite the hardy nature of African catfish, more than $70 \%$ of the population was lost in the control due to deteriorated quality of the water (Table 2). DO was average $2.2 \mathrm{mg} \mathrm{l}^{-1}$ while $\mathrm{pH}$ was slightly acidic (6.01). Buentello et al. (2000), Pichavant et al. (2001), O'Bryen and Lee (2007) had stressed the fact that fish start to lose appetite when the oxygen content drops below $60 \%$ of its saturation level. Bergheim et al. (2005) also pointed out that as oxygen levels decrease, the fish do not have enough energy to swim, more so feeding utilises yet more oxygen, hence the observation of higher percentage of uneaten feed in the ponds with water renewal done weekly or more often. Nordgarden et al. (2003) concluded that elevated symptoms of oxygen deficiency in ponds are often mistaken for diseased fish because fishes in oxygen deficient water do not take food. Daily renewal leads to best water quality recorded in the study but was not translated in performance which is the main essence of fish culture. This scenario may not play out in more advanced aquaculture systems (RAS, raceway, etc.) where water is constantly and automatically renewed on daily or even hourly bases. This is because over time the fish becomes used to the living conditions which are mainly digitally oriented with little or no human interference, and hence minimal stress to fish.

Table 2. Mean water quality parameters monitored during the experimental period

\begin{tabular}{cccccc}
\hline \hline Treatment & $\mathrm{pH} \pm \mathrm{SE}$ & $\mathrm{DO}(\mathrm{mg} / \mathrm{I})$ & Temperature $\left.^{\circ} \mathrm{C}\right)$ & TDS $(\mathrm{ppm})$ & Conductivity $(\mu \mathrm{s})$ \\
\hline Trt1 & $7.53 \pm 0.005^{\mathrm{a}}$ & $5.60 \pm 0.020^{\mathrm{a}}$ & $26.10 \pm 0.002$ & $271.50 \pm 1.500^{\mathrm{e}}$ & $543.0 \pm 3.00^{\mathrm{e}}$ \\
Trt2 & $7.50 \pm 0.001^{\mathrm{b}}$ & $4.00 \pm 0.005^{\mathrm{b}}$ & $26.10 \pm 0.001$ & $419.50 \pm 0.500^{\mathrm{d}}$ & $838.0 \pm 2.00^{\mathrm{d}}$ \\
Trt3 & $7.49 \pm 0.005^{\mathrm{b}}$ & $3.70 \pm 0.001^{\mathrm{c}}$ & $26.08 \pm 0.01$ & $428.00 \pm 0.020^{\mathrm{c}}$ & $856.0 \pm 1.400^{\mathrm{c}}$ \\
Trt 4 & $7.42 \pm 0.005^{\mathrm{c}}$ & $3.00 \pm 0.002^{\mathrm{d}}$ & $26.10 \pm 0.20$ & $697.00 \pm 0.003^{\mathrm{b}}$ & $1394.0 \pm 1.004^{\mathrm{b}}$ \\
Trt 5 & $6.01 \pm 0.005^{\mathrm{d}}$ & $2.20 \pm 0.002^{\mathrm{e}}$ & $26.10 \pm 0.01$ & $721.00 \pm 0.03^{\mathrm{a}}$ & $1559.0 \pm 0.04^{\mathrm{a}}$ \\
\hline \hline
\end{tabular}

Means with the same superscript on the same column are not significantly different $(P>0.05)$ 


\section{Sažetak}

\section{UČINAK OBNAVLJANJA VODE NA RAST MLAĐI Clarius gariepinus}

Cilj ovog istraživanja je utvrditi utjecaj različitih frekvencija promjene vode na rast afričkog soma, Clarius gariepinus. Mlađ s početnim srednjim težinama od 7,02 $\pm 0,05 \mathrm{~g}$ je bila smještena (po 50 riba u svaki) u petnaest betonskih spremnika ( $2 \times 2 \times 2 \mathrm{~m})$ koji su tretirani s pet različitih tretmana obnavljanja vode i to: TRT1 (bez promjene vode), TRT2 (dnevna promjena vode), TRT3 (voda se obnavljala nakon četiri dana), TRT4 (voda se obnavljala nakon osam dana) i TRT5 (voda se obnavljala nakon četrnaest dana). Nakon 56 dana hranjenja, najbolje rezultate rasta je pokazala mlađ u spremnicima s frekvencijom obnavljanja vode od TRT3 i TRT4. Slično tome, preživljavanje je bilo više u tim frekvencijama u usporedbi s ostalima. Međutim, kontrolni tretman je imao najmanji učinak za sve mjerene parametre. Stoga se preporučuje da se radi obnova vode nakon četiri do osam dana kako bi se poboljšalo rast mlađi afričkih somova uzgojenih u statičkom sustavu.

Ključne riječi: promjena vode, opstanak, parametri rasta, kvaliteta vode

\section{REFERENCES}

Adesulu, E. A. (2001): Pisciculture: Essential production information. $1^{\text {st }}$ Edition. Eternal. Communication Limited, Lagos. Nigeria 118pp.

Agarwal, V. P. (1999): Recent trends in aquaculture. Agarwal Printers, 1174, P. Sharma Road, Meerut. 550- 556.

Ajana, A. M., Adekoya, B. B. O., Agankanuwo, J. O. (2006): Practical fish farming by alliance for community information, Nigeria, 88pp.

AOAC, (2000): Official method of analysis. Association of Analytical Chemists, $17^{\text {th }}$ ed Washington DC.

Bergheim, A., Gausen, M., Naes, A., Holland, P. M., Krogedal, P., Crampton, V. (2005): A newly developed oxygen injection system for cage farms. Aquacultural Engineering 34 , 40-46.

Boyd, C. E. (2001): Water quality standards, Global Aquaculture Advocate 4, 1, 42-44

Boyd, C. E. (1990): Water quality in ponds for aquaculture. Alabama Agricultural Experimental Station. Auburn University, Auburn, USA.

Buentello, J. A., Gatlin III, D. M., Neill, W. H. (2000): Effects of water temperature and dissolved oxygen on daily feed consumption, feed utilization and growth of channel catfish (Ictalurus punctatus). Aquaculture 182, 339-352.

Collins, P. (1994): Growth response and fatty acid composition of channel catfish fed practical diets. Progressive fish culturist 53,135-140

Egwui, P. C., Ezeonyejiaku, C. D. Ezeobi, A. J. (2014): Effects of water renewal on the growth and survival of reared Clarias gariepinus fingerlings. Frontiers of Biological and Life Sciences. 2, 4, 71-73.

FAO (2006): State of world fisheries and Aquaculture. FAO report 2006, available online at ftp://ftp.fao.org/docrep/ fao/011/i0250e/i0250e.pdf

FAO (2012): State of the world fisheries and Aquaculture. FAO report available online at http://www.fao.org/3/ai3720e.pdf

Gramma, G., Ajana A., Pichavant K. (2011): Nutritional and feeding of fish. Kluwer Academic Publishers. Second edition

Basu, S. P. (2011): Active respiration of fish in relation to ambient concentration of oxygen and carbon dioxide. J. Fish Res. Bd. Canada, 16 (2): 175-212.

Minitab 17 Statistical Software (2010): [Computer software]. State College, PA: Minitab, Inc. (www.minitab.com)

Moyle, B. P., Cech J. J. Jr (2000): Fishes: An introduction to Ichthyology. Fourth edition. Upper Saddle River NJ 07458.

Neuman, J., Weir, M., Beattie, C., (2004): Skretting in the UK and Chile: An opportunity for comparison. Skretting Outlook 21, 8-11

Nordgarden, U., Oppedal, F., Taranger, G.L., Hemre, G.-I., Hansen, T. (2003): Seasonally changing metabolism in Atlantic salmon (Salmo salar L.). Aquac. Nutr. 9, 287289.

O'Bryen, P. J., Lee, C. S. (2007): Effect of diet, food consumption, growth and retention of protein and energy. Diss Auburn University Auburn, Alabama.51pp

Olivier, M., Gäelle, G., Avelina, L., Trinh, D., Pham, T., (2006): Local fish farming practices and a typology of farms based on organic matter intake management. V. Porphyre Nguyen Que Coi. Pig Production Development, AnimalWaste Management and Environment Protection: a Case Study in Thai Binh Province, Northern Vietnam, CIRADPRISE publications, pp.107-125.

Pichavant, K., Pearson-Le-Ruyet, J., Le Bayon, N., Severe, A., Le Roux, A., Beouf, G. (2001): Comparative effects of long-term hypoxia on growth, feeding and oxygen consumption in juvenile turbot and European sea bass. J. Fish Biol. 59: 875-883.

Poon, W. L, Hung, C. Y., Randall, D. J. (2002): The effect of aquatic hypoxia on fish. Department of Biology and Chemistry, City University of Hong Kong, Kowloon, Hong Kong, SAR, China. EPA/600/R-02/097.

Tom, L. (1998): Nutritional and feeding of fish. Kluwer Academic Publishers. Second edition.

Ugwumba, A. A., Ugwumba, O. A., (2007): Food and feeding ecology of fishes in Nigeria, $1^{\text {st }}$ edition, Crystal publication, Ajah, Lagos. 4, pp 91. 
Appendix 1. Commonly used water renewal frequencies among Nigerian Aquaculturist

\section{SECTION A (Kindly fill as appropriate)}

Name:

Age:

Sex:

Occupation:

Years of experience in Aquaculture practices:

SECTION B (kindly tick as appropriate)

\begin{tabular}{|c|c|c|c|c|}
\hline Types of Pond used: & Concrete & Earthen & Fibre glass & Collapsible \\
\hline Number of stock pond in facility: & $<5$ & $6-15$ & $16-25$ & $25>$ \\
\hline Scale of Aquaculture Production: & Small & Medium & Large & \\
\hline Water source: & Tap & River & Borehole & Others:.... \\
\hline
\end{tabular}

Type of Aquaculture System used: Static

Water renewal Frequencies: Daily

Flow through $\square \quad$ Recirculatory

After two weeks

After four day

After eight days

*Others:

Reason for selected renewal Freq: Choice $\square \quad$ Chance $\square \quad$ Water availability Ideal recommendation

Average mortality percentages:

$<10 \% \quad \square \quad-21-25 \%$

$26-50 \%$

$>51 \%$

Would you recommend your :

Yes

Current practice to a novice

in aquaculture?

No

(State reasons for your answer) 